OPEN ACCESS

Edited by:

Musharraf Jelani,

King Abdulaziz University, Saudi Arabia

Reviewed by:

Helena Caria,

Instituto de Biossistemas e Ciências

Integrativas (Bio/SI), Portugal

Muhammad Tariq

University of Tabuk, Saudi Arabia

${ }^{*}$ Correspondence:

Min Gao

ahhngm@126.com

tThese authors have contributed equally to this work

Specialty section:

This article was submitted to Genetic Disorders,

a section of the journal

Frontiers in Genetics

Received: 12 September 2018 Accepted: 29 November 2018 Published: 07 January 2019

Citation:

Li Y, Tang L, Han Y, Zheng L, Zhen Q, Yang $S$ and Gao M (2019) Genetic Analysis of KRT9 Gene Revealed Previously Known Mutations and Genotype-Phenotype Correlations in Epidermolytic Palmoplantar Keratoderma. Front. Genet. 9:645. doi: 10.3389/fgene.2018.00645

\section{Genetic Analysis of KRT9 Gene Revealed Previously Known Mutations and Genotype-Phenotype Correlations in Epidermolytic Palmoplantar Keratoderma}

\author{
Yuwei $\mathrm{Li}^{1,2 \dagger}$, Lili Tang ${ }^{1,2 \dagger}$, Yang Han ${ }^{1,2}$, Liyun Zheng ${ }^{1,2}$, Qi Zhen ${ }^{1,2}$, Sen Yang ${ }^{1}$ and Min Gao ${ }^{1 *}$ \\ ${ }^{1}$ Institute of Dermatology and Department of Dermatology of First Affiliated Hospital, Hefei, China, ${ }^{2}$ Key Laboratory of \\ Dermatology, Ministry of Education, Anhui Medical University, Hefei, China
}

Epidermolytic palmoplantar keratoderma (EPPK, OMIM 144200) is an autosomal dominant inherited disease, clinically characterized by diffuse yellowish thickening of the skin on the palms and soles, usually with erythematous borders developing during the first weeks or months after birth. Pathogenesis of EPPK is determined by mutations in the keratin gene (KRT9). Thirty three mutations in the KRT9 gene from 100 EPPK families have been identified. Among these, 23 mutations are located in the $1 \mathrm{~A}$ region (a mutation hot spot region), 7 are located in the 2B region, and the remaining 3 are synonymous mutations. In this study, three heterozygous mutations (p.N161S, p.R163W, and p.R163Q), located in regions of the gene encoding the conserved central a-helix rod domain, were detected in the KRT9 gene of the three large Chinese families. This study confirms that codon 163 (48 of 100 cases) is a hot spot mutation site for KRT9. Additional findings identified p.N161S (4\%) and p.R163W (4\%) as potential hot spot mutations for EPPK associated with knuckle pads, and p.R163Q (15 of 100 cases) as the hot spot mutation of EPPK not occurring in combination with knuckle pads. In conjunction with future studies, this research may help lay the foundation for genetics counseling, prenatal diagnosis and clinical treatment of EPPK.

Keywords: epidermolytic palmoplantar keratoderma, gene mutation, hot spot, KRT9 gene, knuckle pads

\section{BACKGROUND}

Epidermolytic palmoplantar keratoderma (EPPK, OMIM 144200), also known as Vorner's palmoplantar keratosis, is an autosomal dominant inherited disease characterized by diffuse, yellow thickening of the palm and sole with an erythematous margin. It was first described in 1901 by Vorner. The incidence rate is approximately 2.2 to 4.4 per 100000 live newborns (Bonifas et al., 1994; Covello et al., 1998; Smith, 2003; Lopez-Valdez et al., 2013; Liu et al., 2014). Some patients may have hyperhidrosis, knuckle pads, camptodactyly and digital mutilation (Lu et al., 2003; Du et al., 2011; Umegaki et al., 2011). Female patients may have an increased risk for ovarian cancer or breast cancer (Hamada et al., 2013). 
A
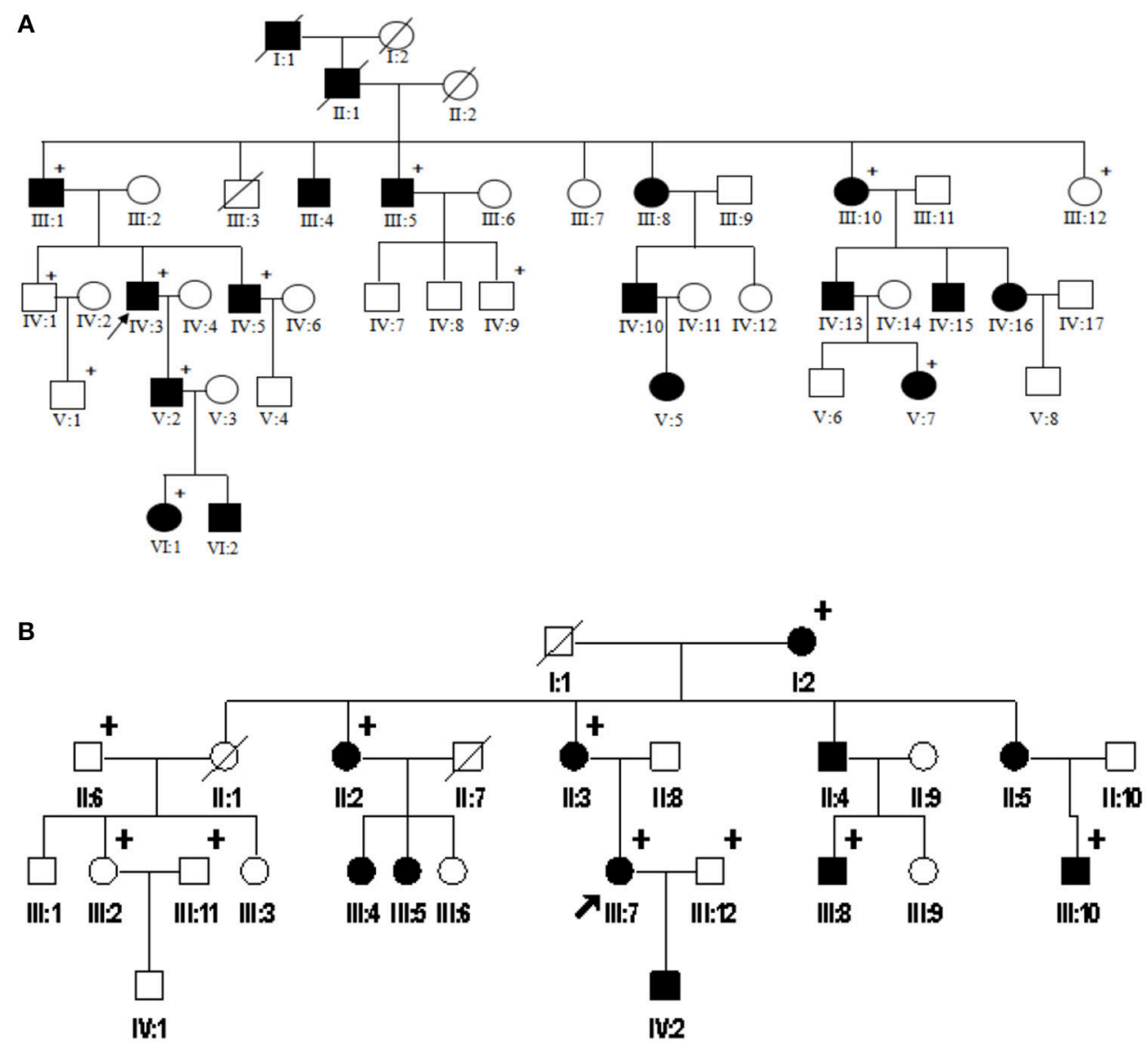

C

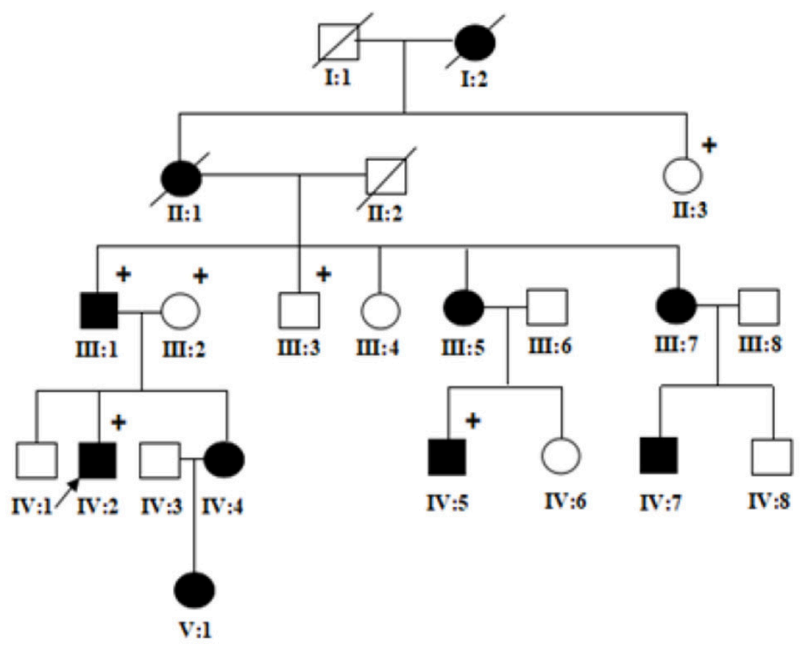

FIGURE 1 | Pedigrees of EPPK families 1 (A), 2 (B), and 3 (C). Arrows show the probands.

Keratin 9 is composed of the functional head domain, the functional $\alpha$-helical domain and the functional tail domain, and is expressed only in the suprabasal layers of the palmoplantar epidermis (Uitto et al., 2007). To date, domestic and foreign scholars have found 33 KRT9 gene mutations in 100 EPPK families, of which 15 cases are associated with knuckle pads.
There is no report making a detailed summary and analysis. In this study, cases of EPPK were analyzed to look for genotypephenotype correlations by searching the database and consulting the literatures, providing a theoretical basis for the prenatal diagnosis of, genetic counseling for, and clinical treatment of EPPK. 

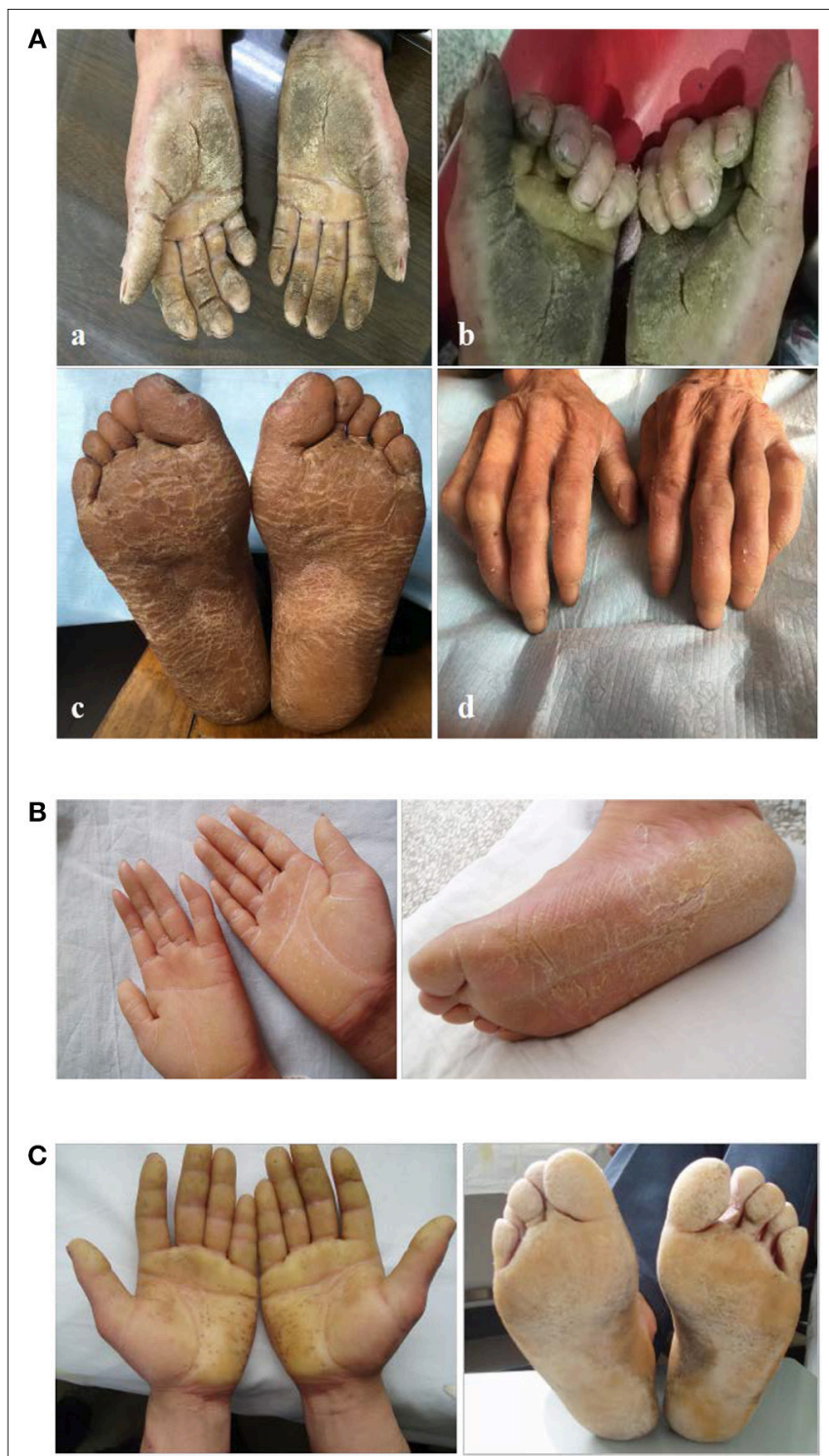

FIGURE 2 | Clinical representations of the proband. (A) Knuckle pads on the dorsal aspect of the proband's hands. (B) Diffuse hyperkeratosis of the proband's palms and soles. (C) Well-demarcated erythematous border of the proband's.

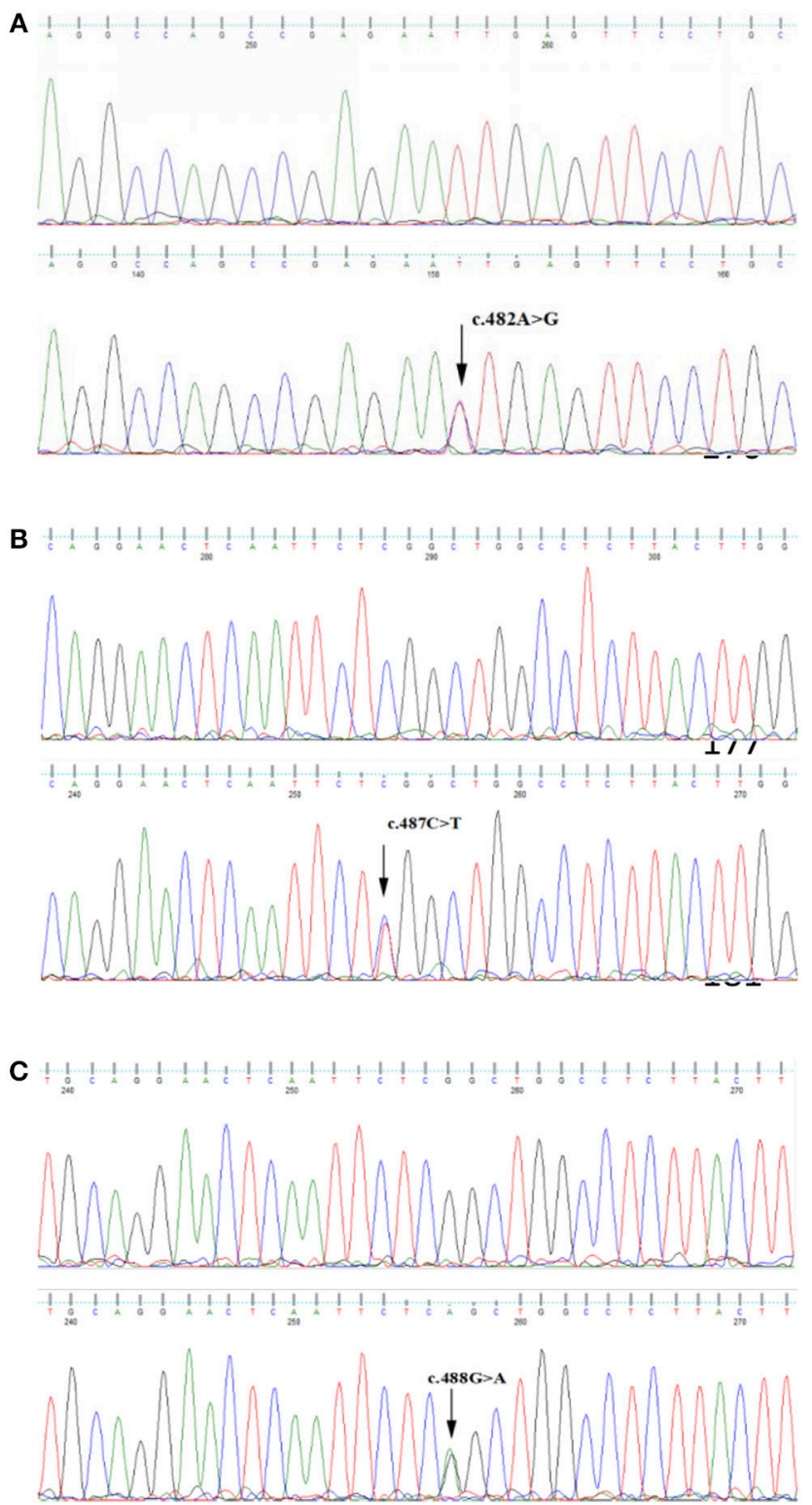

FIGURE 3 | (A) Heterozygous variants c.482A>G identified in Family PPK-1. (B) Heterozygous variants c.487C $>T$ identified in Family PPK-2. (C) Heterozygous variants c.488G $>$ A identified in Family PPK-3.

\section{COMPLIANCE WITH ETHICAL STANDARDS}

All procedures performed in studies involving human participants were in accordance with the ethical standards of the institutional and/or national research committee and with the 1964 Helsinki declaration and its later amendments or comparable ethical standards. Informed written consents were obtained from all individual participants or their legal representatives (parents) included in the study. The study was approved without restrictions by the Medical Ethics Committee of the First Affiliated Hospital of Anhui Medical
University. The probands and their family members provided written informed consent for the publication of this case report.

\section{CASE PRESENTATION}

Three unrelated Chinese EPPK pedigrees from Shandong and Anhui Province were investigated. All patients exhibited typical EPPK features. There were no close relatives bettwen these families. Family 1 was a six generational EPPK pedigree with 17 affected members, including 11 males 
TABLE 1 | Mutations analysis in KRT9 gene of EPPK.

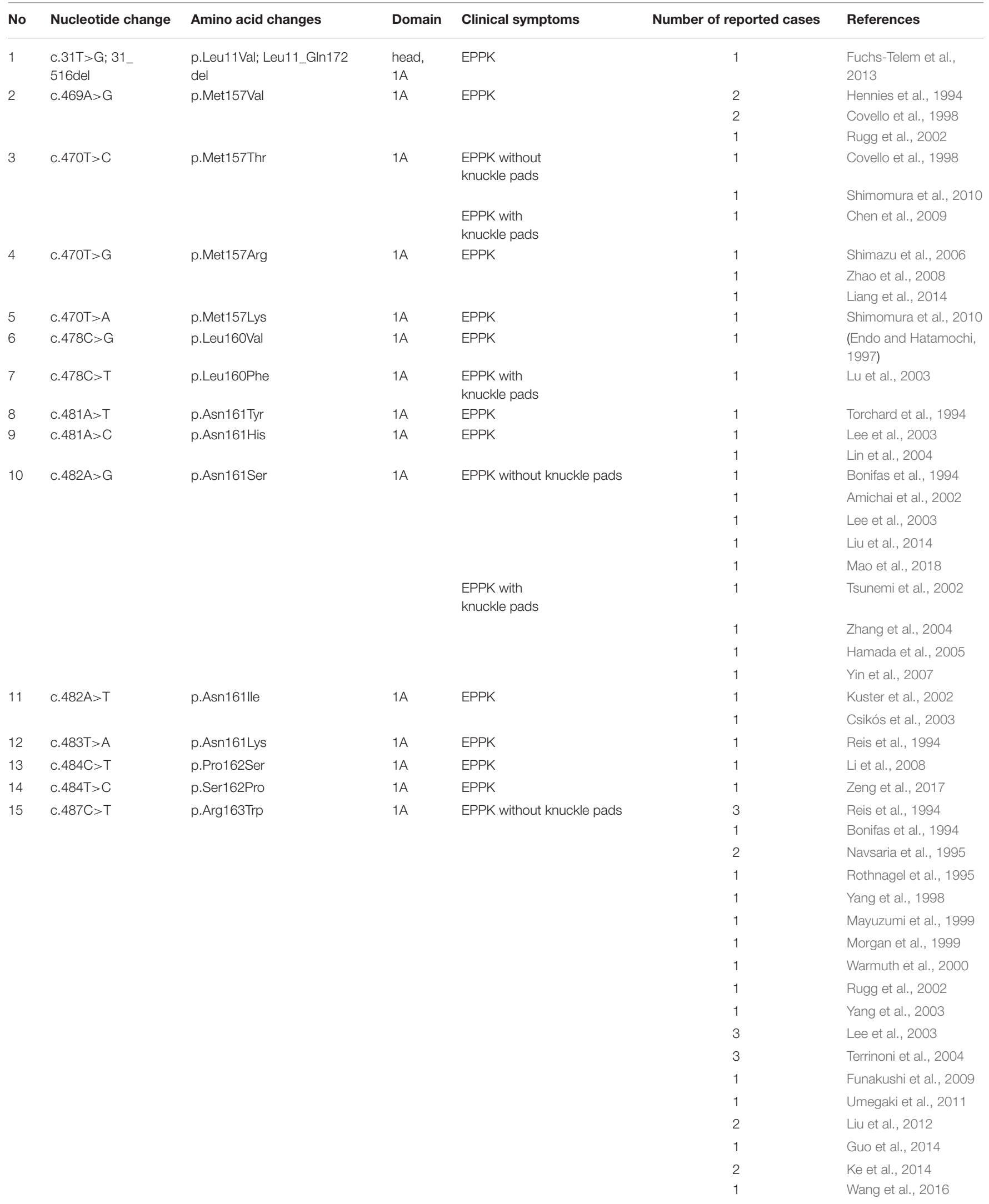

(Continued) 
TABLE 1 | Continued

\begin{tabular}{|c|c|c|c|c|c|c|}
\hline No & Nucleotide change & Amino acid changes & Domain & Clinical symptoms & Number of reported cases & References \\
\hline & & & & $\begin{array}{l}\text { EPPK with } \\
\text { knuckle pads }\end{array}$ & 1 & Mao et al., 2018 \\
\hline & & & & & 1 & Chiu et al., 2007 \\
\hline & & & & & 1 & Codispoti et al., 2009 \\
\hline & & & & & 1 & $\begin{array}{l}\text { Lopez-Valdez et al., } \\
2013\end{array}$ \\
\hline \multirow[t]{14}{*}{16} & c. $488 \mathrm{G}>\mathrm{A}$ & p.Arg163Gln & $1 \mathrm{~A}$ & EPPK & 1 & Reis et al., 1994 \\
\hline & & & & & 1 & Kobayashi et al., 1996 \\
\hline & & & & & 1 & Yang et al., 1998 \\
\hline & & & & & 1 & Covello et al., 1998 \\
\hline & & & & & 1 & Szalai et al., 1999 \\
\hline & & & & & 1 & Rugg et al., 2002 \\
\hline & & & & & 1 & $\begin{array}{l}\text { Wennerstrand et al., } \\
2003\end{array}$ \\
\hline & & & & & 1 & Yang et al., 2003 \\
\hline & & & & & 1 & Sun et al., 2005 \\
\hline & & & & & 2 & Shimomura et al., 2010 \\
\hline & & & & & 1 & Li et al., 2012 \\
\hline & & & & & 1 & Ke et al., 2014 \\
\hline & & & & & 1 & Zhang et al., 2016 \\
\hline & & & & & 1 & Mao et al., 2018 \\
\hline 17 & c. $488 \mathrm{G}>\mathrm{C}$ & p.Arg163Pro & $1 \mathrm{~A}$ & EPPK & 1 & Kon et al., 2006 \\
\hline 18 & c. $491 \mathrm{~T}>\mathrm{C}$ & p.Leu164Pro & $1 \mathrm{~A}$ & EPPK & 1 & Mao et al., 2018 \\
\hline \multirow[t]{2}{*}{19} & c.500_500delAinsGGC & Tp.Tyr167delinsTrpLeu & $1 \mathrm{~A}$ & EPPK & 1 & He et al., 2004 \\
\hline & & & & & 3 & Zhang et al., 2005 \\
\hline \multirow[t]{3}{*}{20} & c.503T>C & p.Leu168Ser & $1 \mathrm{~A}$ & $\begin{array}{l}\text { EPPK with } \\
\text { knuckle pads }\end{array}$ & 1 & Rothnagel et al., 1995 \\
\hline & & & & & 1 & Yin et al., 2007 \\
\hline & & & & & 1 & Li et al., 2009 \\
\hline 21 & c. $508 \mathrm{~A}>\mathrm{T}$ & p.Lys170X & $1 \mathrm{~A}$ & EPPK & 1 & Szalai et al., 1999 \\
\hline 22 & c. $511 \mathrm{G}>\mathrm{A}$ & p.Val171Met & $1 \mathrm{~A}$ & EPPK & 1 & Rugg et al., 2002 \\
\hline 23 & c.515A>C & p.GIn172Pro & $1 \mathrm{~A}$ & EPPK & 1 & Hennies et al., 1994 \\
\hline 24 & c. $1216 \mathrm{~T}>\mathrm{C}$ & p.Cys406Arg & $2 \mathrm{~B}$ & $\begin{array}{l}\text { EPPK with } \\
\text { knuckle pads }\end{array}$ & 1 & Wang et al., 2010 \\
\hline 25 & c. $1282 \mathrm{C}>\mathrm{T}$ & p.Gln428X & $2 \mathrm{~B}$ & EPPK & 1 & Umegaki et al., 2011 \\
\hline 26 & c. $1360 T>C$ & p.Tyr454His & $2 \mathrm{~B}$ & EPPK & 1 & Shimomura et al., 2010 \\
\hline 27 & c.1362_1363insCAC & p.Tyr454_His 455insHis & $2 \mathrm{~B}$ & EPPK & 1 & Coleman et al., 1999 \\
\hline 28 & c. $1369 \mathrm{C}>\mathrm{T}$ & p. Leu457Phe & $2 \mathrm{~B}$ & EPPK & 1 & Xiao et al., 2018 \\
\hline 29 & c. $1372 \mathrm{C}>\mathrm{T}$ & p.Leu458Phe & $2 \mathrm{~B}$ & EPPK & 1 & Kon et al., 2006 \\
\hline 30 & c.1373 T >C & p.L458P & 2B & $\begin{array}{l}\text { EPPK with } \\
\text { knuckle pads }\end{array}$ & 1 & Du et al., 2011 \\
\hline
\end{tabular}

3 synonymous mutations are not listed.

and 6 females. The minimum age of onset is 1 year of age. The proband was a 42-year-old man who presented with diffuse thickening and hyperkeratosis on palms with the nails being normal, and combined knuckle pads, hyperhidrosis and camptodactyly (Figures 1A, 2A). There is no evidence that the proband was associated with other diseases. Family 2 was a 4 generational EPPK pedigree with 11 affected members, and the 20-year-old female proband presented with diffuse thickening and hyperkeratosis on palms and soles (Figures 1B, 2B). Family 3 was a 5 generational EPPK pedigree with 10 affected members, and the proband was a 42-year-old man who demonstrated hyperkeratosis of both palmar and plantar skin within 1 year of birth (Figures 1C, 2C). 


\section{LABORATORY INVESTIGATIONS}

\section{Genetic Testing and Confirmation of Mutation}

Peripheral blood samples were collected from members of the three families and 100 healthy unrelated Chinese individuals. Genomic DNA was extracted using a Flexi Gene DNA Kit (250). The primers were amplified by polymerase chain reaction (PCR) and PCR products were directly sequenced by an ABI3730 DNA Sequencer (ABI, USA). The sequence was analyzed by Chromas 2.0 software.

\section{Identification of Three Distinct Mutations in the KRT9 Gene of Three Large Chinese Families}

Patients of family 1 had a heterozygous mutation c.482A>G (P.Asn161His) in KRT9 gene (Figure 3A). Patients of family 2 had a heterozygous mutation c.487C $>\mathrm{T}$ (p.Arg163Trp) in KRT9 gene (Figure 3B). Patients of family 3 had a heterozygous mutation c.488G > A (p.Arg163Gln) in KRT9 gene (Figure 3C). These mutations were not found in normal members of three families and in 100 healthy controls.

\section{Genetic Characteristics of the Mutation in the KRT9 Gene}

This study searched the human intermediate filament database (http://www.interfil.org/index.php), PubMed (https://www.ncbi. nlm.nih.gov/pubmed), China National Knowledge Internet (http://www.cnki.net/), and a large portion of literature and found that 33 KRT9 gene mutations were reported in $100 \mathrm{EPPK}$ families by domestic and foreign scholars (Table 1). Disease causing mutations are as follows: of which 23 are located in the $1 \mathrm{~A}$ region (hot spot mutation region), 7 in the $2 \mathrm{~B}$ region, and the remaining 3 are synonymous mutations. Missense mutations at amino acid 163 (48\% of all mutations) is indeed a hot spot mutation site for KRT9. We also found that the mutations of EPPK associated with knuckle pads (15\% of 100 cases) are p.N161S (4\%), p.R163W (4\%), p.L168S (3\%), p.M157T (1\%), p.L160F (1\%), p.C406R (1\%), and p.L458p (1\%). Since these mutations are the most prevalent we can suggest that p.N161S and p.R163W are potential hot spot mutations of EPPK associated with knuckle pads. The hot spot mutation of EPPK not associated with knuckle pads is p.R163Q (15 of 100 cases).

\section{DISCUSSION}

Epidermolytic palmar hyperkeratosis (EPPK) is rare in clinical settings with a prevalence of $\sim 4.4 / 100,000$. In mild cases, only the epidermis of the palmoplantar is rough, and severe horny thickening plaques appear in the palmoplantar region. It may even spread to the lateral edge of the palmoplantar skin or the hands and feet and may be accompanied by knuckle pads and finger-toe flexion deformities. The keratin mutations that have been found so far are concentrated in the $1 \mathrm{~A}$ helix region and the $2 \mathrm{~B}$ helix region, namely, the KRT9 gene mutation hot spot (Guo et al., 2014; Liang et al., 2014), especially the $1 \mathrm{~A}$ region, which affects the formation of keratinous network structures leading to severe clinical manifestations.

Researchers at home and abroad have found that the 163rd amino acid is the hotspot mutation region of the KRT9 gene (48 of 100 cases) (Rugg et al., 2002). EPPK combined with knuckle pads maybe associated with mutations in many KRT9 genes, such as p.Met157Thr, p.Leu160Phe, p.Asn161Ser,p.Arg163Trp, p.Leu168Ser, p.Cys406Arg, and p.Leu458Pro (Escobar et al., 2007; Codispoti et al., 2009; Li et al., 2009; Wang et al., 2010; Du et al., 2011; Mao et al., 2018; Xiao et al., 2018). In this study, we studied three large Chinese families with EPPK and found 3 heterozygous gene mutations of KRT9: c.482A > G (p.Asn161Ser), c.487C > T (p.Arg163Trp) and c.488G $>$ A (p.Arg163Gln). These mutations were not found in normal members of three families and in 100 healthy controls, indicating that the mutations detected in the families were the pathogenic mutations. The mutation p.Asn161Ser has been reported several times in relation to the typical hyperkeratotic manifestations of palmoplantar skin in patients with EPPK, but it has not been associated with other clinical phenotypes. In 2005, Japanese scholars reported a case of EPPK in a 13-yearold patient with knuckle pads, and the genetic test results were found to be associated with the mutation p.Asn161Ser. In this study, the pathogenic mutation of family 1 was p.Asn161Ser, and all patients in the family showed knuckle pads, consistent with previous reports. This study found that 33 KRT9 gene mutations in 100 EPPK families have been reported by domestic and foreign scholars, and the mutations of EPPK associated with knuckle pads (15 of 100 cases) are p.N161S (4\%), p.R163W (4\%), p.L168S (3\%), p.M157T (1\%), p.L160F (1\%), p.C406R (1\%), and p.L458p (1\%), suggesting p.N161S and p.R163W are potential hot spot mutations of EPPK associated with knuckle pads, and p.R163Q (15 of 100 cases) as the hot spot mutation of EPPK not occurring in combination with knuckle pads.Based on the above studies, this case reveals knuckle pads may also be one of the less common clinical phenotypes of EPPK, and we think this study should help lay the foundation for genetics counseling, prenatal diagnosis and clinic treatment of EPPK.

\section{AUTHOR CONTRIBUTIONS}

All authors listed have made a substantial, direct and intellectual contribution to the work, and approved it for publication.

\section{ACKNOWLEDGMENTS}

We would like to thank the individuals and their families who participated in this project. This research did not receive any specific grant from funding agencies in the public, commercial, or not-for-profit sectors. 


\section{REFERENCES}

Amichai, B., Karpati, M., and Goldman, B. L. P. (2002). Keratin-9 gene mutation in a family with epidermolytic palmoplantar keratoderma. J. Eur. Acad. Dermatol. Venereol. 16, 134-136. doi: 10.1046/j.1468-3083.2002.00426.x

Bonifas, J. M., Matsumura, K., Chen, M. A., Berth-Jones, J., Hutchison, P. E., Zloczower, M., et al. (1994). Mutations of keratin 9 in two families with palmoplantar epidermolytic hyperkeratosis. $J$. Invest. Dermatol. 103, 474-477. doi: 10.1111/1523-1747.ep123 95570

Chen, X. L., Xu, C. M., Cai, S. R., Chen, C. Y., and Zhang, X. N. (2009). Prenatal diagnosis of epidermolytic palmoplantar keratoderma caused by c.T470C (p.M157T) of the keratin 9 gene in a Chinese kindred. Prenat. Diagn. 29, 911-913. doi: 10.1002/pd.2315

Chiu, H. C., Jee, S. H., Sheen, Y. S., Chu, C. Y., Lin, P. J., and Liaw, S. H. (2007). Mutation of keratin 9 (R163W) in a family with epidermolytic palmoplantar keratoderma and knuckle pads. J. Dermatol. Sci. 45, 63-65. doi: 10.1016/j.jdermsci.2006.09.005

Codispoti, A., Colombo, E., Zocchi, L., Serra, V., Pertusi, G., Leigheb, G., et al. (2009). Knuckle pads, in an epidermal palmoplantar keratoderma patient with Keratin 9 R163W transgrediens expression. Eur. J. Dermatol. 19, 114-118. doi: 10.1684/ejd.2008.0575

Coleman, C. M., Munro, C. S., Smith, F. J., and Uitto, J. W. H. (1999). Epidermolytic palmoplantar keratoderma due to a novel type of keratin mutation, a 3-bp insertion in the keratin 9 helix termination motif. $\mathrm{Br}$. J. Dermatol. 140, 486-190. doi: 10.1046/j.1365-2133.1999.02715.x

Covello, S. P., Irvine, A. D., McKenna, K. E., Munro, C. S., Nevin, N. C., and Smith, F. J. (1998). Mutations in keratin K9 in kindreds with epidermolytic palmoplantar keratoderma and epidemiology in northern ireland. J. Invest. Dermatol. 111, 1207-1209. doi: 10.1046/j.1523-1747.1998.00445.x

Csikós, M., Holló, P., Becker, K., Rácz, E., and Horváth, A. S. K. (2003). Novel N160I mutation of keratin 9 in a large pedigree from Hungary with epidermolytic palmoplantar keratoderma. Acta Derm. Venereol. 83, 303-305. doi: 10.1080/00015550310016652

Du, Z. F., Wei, W., Wang, Y. F., Chen, X. L., Chen, C. Y., Liu, W. T., et al. (2011). A novel mutation within the $2 \mathrm{~B}$ rod domain of keratin 9 in a Chinese pedigree with epidermolytic palmoplantar keratoderma combined with knuckle pads and camptodactyly. Eur. J. Dermatol. 21, 675-679. doi: 10.1684/ejd.2011.1458

Endo, H., and Hatamochi, A. H. (1997). A novel mutation of a leucine residue in coil 1A of keratin 9 in epidermolytic palmoplantar keratoderma. J. Invest. Dermatol. 109, 113-115. doi: 10.1111/1523-1747.ep12276751

Escobar, L. F., Heiman, M., Zimmer, D., and Careskey, H. (2007). Urorectal septum malformation sequence: prenatal progression, clinical report, and embryology review. Am. J. Med. Genet. A 143A, 2722-2726. doi: 10.1002/ajmg.a.31925

Fuchs-Telem, D., Padalon-Brauch, G., Sarig, O., and Sprecher, E. (2013). Epidermolytic palmoplantar keratoderma caused by activation of a cryptic splice site in KRT9. Clin. Exp. Dermatol. 38, 189-192: quiz 192. doi: $10.1111 /$ ced.12059

Funakushi, N., Mayuzumi, N., and Sugimura, R. S. I. (2009). Epidermolytic palmoplantar keratoderma with constriction bands on bilateral fifth toes. Arch. Dermatol. 145, 609-610. doi: 10.1001/archdermatol.2009.83

Guo, Y., Shi, M., Tan, Z. P., and Shi, X. L. (2014). Possible anticipation in familial epidermolytic palmoplantar keratoderma with the p.R163W mutation of Keratin 9. Genet. Mol. Res. 13, 8089-8093. doi: 10.4238/2014.October.7.3

Hamada, T., Ishii, N., Karashima, T., and Kawano, Y. (2005). The common KRT9 gene mutation in a Japanese patient with epidermolytic palmoplantar keratoderma and knuckle pad-like keratoses. J. Dermatol. 32, 500-502. doi: 10.1111/j.1346-8138.2005.tb00789.x

Hamada, T., Tsuruta, D., Fukuda, S., Ishii, N., Teye, K., Numata, S., et al. (2013). How do keratinizing disorders and blistering disorders overlap? Exp. Dermatol. 22, 83-87. doi: 10.1111/exd.12021

He, X. H., Zhang, X. N., Mao, W., Chen, H. P., Xu, L. R., Chen, H., et al. (2004). A novel mutation of keratin 9 in a large Chinese family with epidermolytic palmoplantar keratoderma. Br. J. Dermatol. 150, 647-651. doi: 10.1111/j.0007-0963.2004.05865.x

Hennies, H. C., Zehender, D., Kunze, J., Küster, W., and Reis, A. (1994). Keratin 9 gene mutational heterogeneity in patients with epidermolytic palmoplantar keratoderma. Hum Genet. 96, 649-654. doi: 10.1007/BF00201564
Ke, H. P., Jiang, H. L., Lv, Y. S., Huang, Y. Z., Liu, R. R., Chen, X. L., et al. (2014). KRT9 gene mutation as a reliable indicator in the prenatal molecular diagnosis of epidermolytic palmoplantar keratoderma. Gene 546, 124-128. doi: 10.1016/j.gene.2014.05.048

Kobayashi, S., Tanaka, T., Matsuyoshi, N., and Imamura, S. (1996). Keratin 9 point mutation in the pedigree of epidermolytic hereditary palmoplantar keratoderma perturbs keratin intermediate filament network formation. FEBS Lett. 386, 149-155. doi: 10.1016/0014-5793(96)00393-6

Kon, A., Ito, N., Kudo, Y., Nomura, K., Yoneda, K., Hanada, K., et al. (2006). L457F missense mutation within the $2 \mathrm{~B}$ rod domain of keratin 9 in a Japanese family with epidermolytic palmoplantar keratoderma. Br. J. Dermatol. 155, 624-626. doi: 10.1111/j.1365-2133.2006.07358.x

Kuster, W., Reis, A., and Hennies, H. C. (2002). Epidermolytic palmoplantar keratoderma of Vorner: re-evaluation of Vorner's original family and identification of a novel keratin 9 mutation. Arch Dermatol Res. 294, 268-272. doi: $10.1007 / \mathrm{s} 00403-002-0328-9$

Lee, J. H., Ahn, K. S., Lee, C. H., and Youn, S. J. (2003). Keratin 9 gene mutations in five Korean families with epidermolytic palmoplantar keratoderma. Exp. Dermatol. 12, 876-881. doi: 10.1111/j.0906-6705.2003.00012.x

Li, M., Yang, L. J., Hua, H. K., Zhu, X. H., and Dai, X. Y. (2009). Keratin9 gene mutation in epidermolytic palmoplantar keratoderma combined with knuckle pads in a large Chinese family. Clin. Exp. Dermatol. 34, 26-28. doi: 10.1111/j.1365-2230.2007.02384.x

Li, M., Zhang, G. L., Zhai, J. X., Wei, L., Zhu, X. H., Dai, X. Y., et al. (2008). [Mutation analysis of the keratin 9 gene in a pedigree with diffuse epidermolytic plamoplantar keratoderma]. Zhonghua Yi Xue Yi Chuan Xue Za Zhi. 25, 387-389. doi: 10.3321/j.issn:1003-9406.2008.04.004

Li, Y. L., Li, N. N., Wang, Y. P., Li, M. R., Dai, L., Deng, Y., et al. (2012). [Mutation analysis of keratin 9 gene in a family with epidermolytic palmoplantar keratoderma]. Zhonghua Yi Xue Yi Chuan Xue Za Zhi. 29, 280-283. doi: 10.3760/cma.j.issn.1003-9406.2012. 03.007

Liang, Y. H., Liu, Q. X., Huang, L., and Zeng, K. (2014). A recurrent p.M157R mutation of keratin 9 gene in a Chinese family with epidermolytic palmoplantar keratoderma and literature review. Int. J. Dermatol. 53, e375e379. doi: $10.1111 /$ ijd.12352

Lin, J. H., Lin, M. H., Yang, M. H., and Chao, S. C. (2004). A novel keratin 9 gene mutation (Asn160His) in a Taiwanese family with epidermolytic palmoplantar keratoderma. Clin. Exp. Dermatol. 29, 308-310. doi: 10.1111/j.1365-2230.2004.01497.x

Liu, N., Shi, H., Kong, X., and Wu, Q. H. (2014). Mutation analysis and prenatal diagnosis of keratin 9 gene in a large Chinese family with epidermolytic palmoplantar keratoderma. Chin J Med Genet. 31, 48-51. doi: 10.3760/cma.j.issn.1003-9406.2014.01.011

Liu, W. T., Ke, H. P., Zhao, Y., Chen, X. L., Lu, J. J., Du, Z. F., et al. (2012). The most common mutation of KRT9, c.C487T (p.R163W), in epidermolytic palmoplantar keratoderma in two large Chinese pedigrees. Anat. Rec. 295, 604-609. doi: 10.1002/ar.22409

Lopez-Valdez, J., Rivera-Vega, M. R., Gonzalez-Huerta, L. M., Cazarin, J., and Cuevas-Covarrubias, S. (2013). Analysis of the KRT9 gene in a Mexican family with epidermolytic palmoplantar keratoderma. Pediatr. Dermatol. 30, 354-358. doi: 10.1111/pde.12027

Lu, Y., Guo, C., Liu, Q., Zhang, X., Cheng, L., Li, J., et al. (2003). A novel mutation of keratin 9 in epidermolytic palmoplantar keratoderma combined with knuckle pads. Am. J. Med. Genet. A 120A, 345-349. doi: 10.1002/ajmg.a. 20090

Mao, B., Zhang, J., You, Y., Xiao, J., and Zhao, X. (2018). Mutations in the highly conserved 1A rod domain of keratin 9 responsible for epidermolytic palmoplantar keratoderma in four Chinese families. J. Dermatol. 45, e45-e46. doi: $10.1111 / 1346-8138.14087$

Mayuzumi, N., Shigihara, T., and Ikeda, S. H. O. (1999). R162W mutation of keratin 9 in a family with autosomal dominant palmoplantar keratoderma with unique histologic features. J. Investig. Dermatol. Symp. Proc. 4, 150-152. doi: 10.1038/sj.jidsp.5640199

Morgan, V. A., Byron, K., Paiman, L., and Varigos, G. A. (1999). A case of spontaneous mutation in the keratin 9 gene associated with epidermolytic palmoplantar keratoderma. Australas. J. Dermatol. 40, 215-216. doi: 10.1046/j.1440-0960.1999.00365.x 
Navsaria, H. A., Swensson, O., Ratnavel, R. C., Shamsher, M., McLean, W. H., Lane, E. B., et al. (1995). Ultrastructural changes resulting from keratin-9 gene mutations in two families with epidermolytic palmoplantar keratoderma. J. Invest. Dermatol. 104, 425-429. doi: 10.1111/1523-1747.ep12666011

Reis, A., Hennies, H. C., Langbein, L., Digweed, M., Mischke, D., Drechsler, M., et al. (1994). Keratin 9 gene mutations in epidermolytic palmoplantar keratoderma (EPPK). Nat. Genet. 6, 174-179. doi: 10.1038/ng0 294-174

Rothnagel, J. A., Wojcik, S., Liefer, K. M., Dominey, A. M., Huber, M., Hohl, D., et al. (1995). Mutations in the 1 A domain of keratin 9 in patients with epidermolytic palmoplantar keratoderma. J. Invest. Dermatol. 104, 430-433. doi: 10.1111/1523-1747.ep12666018

Rugg, E. L., Common, J. E., Wilgoss, A., Stevens, H. P., Buchan, J., and Leigh, I. M. (2002). Diagnosis and confirmation of epidermolytic palmoplantar keratoderma by the identification of mutations in keratin 9 using denaturing high-performance liquid chromatography. Br. J. Dermatol. 146, 952-957. doi: 10.1046/j.1365-2133.2002.04764.x

Shimazu, K., Tsunemi, Y., Hattori, N., Saeki, H., Komine, M., Adachi, M., et al. (2006). A novel keratin 9 gene mutation (Met156Arg) in a Japanese patient with epidermolytic palmoplantar keratoderma. Int. J. Dermatol. 45, 1128-1130. doi: 10.1111/j.1365-4632.2006.02910.x

Shimomura, Y., Wajid, M., Weiser, J., Kraemer, L., and Christiano, A. M. (2010). Mutations in the keratin 9 gene in Pakistani families with epidermolytic palmoplantar keratoderma. Clin. Exp. Dermatol. 35, 759-764. doi: 10.1111/j.1365-2230.2009.03700.x

Smith, F. J. D. (2003). The molecular genetics of keratin disorders. Am. J. Clin. Dermatol. 4, 347-364. doi: 10.2165/00128071-200304050-00005

Sun, X., Yin, X. Z., Wu, L. Q., Shi, X. L., Hu, Z. M., Liu, X. P., et al. (2005). [Hotspot of the mutations of keratin 9 gene in a diffuse palmoplantar keratoderma family]. Zhong Nan Da Xue Xue Bao Yi Xue Ban 30, 521-524. doi: 10.3321/j. issn:1672-7347.2005.05.005

Szalai, S., Szalai, C., and Becker, K. E. T. (1999). Keratin 9 mutations in the coil 1A region in epidermolytic palmoplantar keratoderma. Pediatr. Dermatol. 16, 430-435. doi: 10.1046/j.1525-1470.1999.00111.x

Terrinoni, A., Cocuroccia, B., Gubinelli, E., Zambruno, G., Candi, E., Melino, G., et al. (2004). Identification of the keratin K9 R162W mutation in patients of Italian origin with epidermolytic palmoplantar keratoderma. Eur. J. Dermatol. 14, 375-378. doi: 10.1111/j.1524-4725.2004.30442_2.x

Torchard, D., Blanchet-Bardon, C., Serova, O., Langbein, L., Narod, S., Janin, N., et al. (1994). Epidermolytic palmoplantar keratoderma cosegregates with a keratin 9 mutation in a pedigree with breast and ovarian cancer. Nat. Genet. 6, 106-110. doi: 10.1038/ng0194-106

Tsunemi, Y., Hattori, N., Saeki, H., and Adachi, M. (2002). A keratin 9 gene mutation (Asn160Ser) in a Japanese patient with epidermolytic palmoplantar keratoderma. J. Dermatol. 29, 768-772. doi: 10.1111/j.1346-8138.2002.tb00220.x

Uitto, J., Richard, G., and McGrath, J. A. (2007). Diseases of epidermal keratins and their linker proteins. Exp. Cell Res. 313, 1995-2009. doi: 10.1016/j.yexcr.2007.03.029

Umegaki, N., Nakano, H., Tamai, K., Mitsuhashi, Y., Akasaka, E., Sawamura, D., et al. (2011). Vorner type palmoplantar keratoderma: novel KRT9 mutation associated with knuckle pad-like lesions and recurrent mutation causing digital mutilation. Br. J. Dermatol. 165, 199-201. doi: 10.1111/j.1365-2133.2011.10317.x

Wang, K., He, C. D., Song, F., Liu, J., and Chen, H. D. (2010). A novel mutation of the keratin 9 gene in a Chinese family with epidermolytic palmoplantar keratoderma. Int. J. Dermatol. 49, 1342-2344. doi: 10.1111/j.1365-4632.2009.04295.x
Wang, P., Kang, X. J., Tang, X. H., Liu, J. Y., Li, W. Z., Wang, W. J., et al. (2016). Six generations of epidermolytic palmoplantar keratoderma, associated with a KRT9 R163W mutation. Cancer Genet. 209, 515-524. doi: 10.1016/j.cancergen.2016.10.002

Warmuth, I., Cserhalmi-Friedman, P. B., Schneiderman, P., Grossman, M. E., and Christiano, A. M. (2000). Epidermolytic palmoplantar keratoderma in a Hispanic kindred resulting from a mutation in the keratin 9 gene. Clin. Exp. Dermatol. 25, 244-246. doi: 10.1046/j.1365-2230.2000.00626.x

Wennerstrand, L. M., Klingberg, M. H., Hofer, P. A., Lundström, A., Lind, L. (2003). Mutation in the keratin 9 gene in a family with epidermolytic palmoplantar keratoderma from northern Sweden. Acta Derm. Venereol. 83, 135-137. doi: 10.1080/00015550310007517

Xiao, H., Guo, Y., Yi, J., Xia, H., Xu, H., Yuan, L., et al. (2018). Identification of a novel keratin 9 missense mutation in a chinese family with epidermolytic palmoplantar keratoderma. Cell. Physiol. Biochem. 46, 1919-1929. doi: 10.1159/000489381

Yang, J. M., Lee, S., Kang, H. J., Lee, J. H., Yeo, U. C., Son, I. Y., et al. (1998). Mutations in the 1A rod domain segment of the keratin 9 gene in epidermolytic palmoplantar keratoderma. Acta Derm. Venereol. 78, 412-416. doi: 10.1080/000155598442674

Yang, M. H., Lee, J. Y., Lin, J. H., and Chao, S. C. (2003). De novo mutation of keratin 9 gene in two Taiwanese patients with epidermolytic palmoplantar keratoderma. J. Formos. Med. Assoc. 102, 492-496. doi: 10.1016/S08853924(03)00203-3

Yin, X. Z., Zhang, B. R., Ding, M. P., Zhang, H., Xia, K., and Hu, Z. M. (2007). [Pathological features and gene mutation analysis in two pedigrees of diffuse palmoplantar keratoderma]. Yi Chuan 29, 301-305. doi: 10.1360/yc007-0301

Zeng, R., He, Y., Hui, Y., Li, Z., Xu, H., Li, M., et al. (2017). Identification of a novel mutation of KRT9 gene in a family with epidermolytic palmoplantar keratoderma. Chin J Lepr Skin Dis. 33, 464-467.

Zhang, B. R., Yin, X. Z., Xia, K., Ding, M. P., Hu, Z. M., Zheng, M., et al. (2004). [Mutation analysis of keratin 9 gene in a pedigree with epidermolytic palmoplantar keratoderma]. Zhonghua Yi Xue Yi Chuan Xue Za Zhi. 21, 570-573. doi: 10.3760/j.issn:1003-9406.2004.06.008

Zhang, X. N., He, X. H., Lai, Z., Yin, W. G., Le, Y. P., Guo, J. M., et al. (2005). An insertion-deletion mutation in keratin 9 in three Chinese families with epidermolytic palmoplantar keratoderma. Br. J. Dermatol. 152, 804-806. doi: 10.1111/j.1365-2133.2005.06477.x

Zhang, Y., Chu, G., Gao, H., He, R., and Zhao, Y. (2016). Mutation analysis of keratin 9 gene in a pedigree with epidermolytic palmoplantar keratoderma. Clin. J. Med. off. 44, 805. doi: 10.16680/j.1671-3826.2016.08.12

Zhao, J. J., Zhang, Z. H., Niu, Z. M., Xiang, L. H., Ye, X. Y., Huang, W., et al. (2008). Mutation M157R of keratin 9 in a Chinese family with epidermolytic palmoplantar keratoderma. Int. J. Dermatol. 47, 634-637. doi: $10.1111 / \mathrm{j} .1365-4632.2008 .03441 . \mathrm{x}$

Conflict of Interest Statement: The authors declare that the research was conducted in the absence of any commercial or financial relationships that could be construed as a potential conflict of interest.

Copyright (C) 2019 Li, Tang, Han, Zheng, Zhen, Yang and Gao. This is an open-access article distributed under the terms of the Creative Commons Attribution License (CC $B Y)$. The use, distribution or reproduction in other forums is permitted, provided the original author(s) and the copyright owner(s) are credited and that the original publication in this journal is cited, in accordance with accepted academic practice. No use, distribution or reproduction is permitted which does not comply with these terms. 